\section{EMBRYRIDDLE}

Aeronautical University

SCHOLARLY COMMONS
Journal of Aviation/Aerospace

Education \& Research

Volume 11

Number 1 JAAER Fall 2001

Article 2

Fall 2001

\title{
Accreditation of Collegiate Aviation's Distance Education \\ Programs: Now and in the Future
}

Brent D. Bowen

bowenb6@erau.edu

Nanette Scarpellini

Mary Fink

finkm3@erau.edu

Follow this and additional works at: https://commons.erau.edu/jaaer

\section{Scholarly Commons Citation}

Bowen, B. D., Scarpellini, N., \& Fink, M. (2001). Accreditation of Collegiate Aviation's Distance Education Programs: Now and in the Future. Journal of Aviation/Aerospace Education \& Research, 11(1).

https://doi.org/10.15394/jaaer.2001.1287

This Article is brought to you for free and open access by the Journals at Scholarly Commons. It has been accepted for inclusion in Journal of Aviation/Aerospace Education \& Research by an authorized administrator of Scholarly Commons. For more information, please contact commons@erau.edu. 


\title{
ACCREDITATION OF COLLEGLATE AVATION'S DISTANCE EDUCATION PROGRAMS: NOW AND IN THE FUTURE
}

\author{
Brent Bowen, Nanette Scarpellini, and Mary Fink
}

\begin{abstract}
The purpose of this research endeavor is to benchmark and evaluate the accreditation status of aviation distance education programs in the United States.' This study examines both the expanding role of distance education as a delivery method for aviation courses as well as the need for establishing standards. The research methods provide data collection through content analysis, literature review, and a survey tool mailed to aviation professionals nationwide. The findings reveal that, in general, most disciplines are either just beginning to approach the subject of distance education accreditation of programs or do not deal with the issue at all. The results of the research reveal a positive interest in distance education and the accreditation process. Further research is recommended to ensure that the accreditation standards and program guidelines fit the needs of distance education and its students.
\end{abstract}

In response to the expanding issue of distance education accreditation, the Council on Aviation Accreditation (CAA) formed the Ad hoc Committee on Distance Education in July of 1997. The committee was assembled both to research the status of distance education programs in various accreditation bodies and to gather information specific to the accreditation of aviation distance education programs. The Ad hoc Committee on Distance Education acknowledges that "...it is evident that a struggle exists to define this rapidly changing issue. An emerging common thread is the conveyance that standards are not exempted for curricula delivered via technology. However, interpretation of standards to accommodate unique and innovative systems for distributed learning is necessary" (p. 1). To meet the mission of the committee, the authors prepared a comprehensive questionnaire regarding the issues and implications of distance education and distributive learning. With the initial pretest complete, the survey was distributed to aviation professionals across the country for direct feedback. The survey is currently available via the World Wide Web (http://cid.unomaha.edu/ unoai/caa/whitepaperaccreditat ion.html\#survey), and feedback will be collected from that medium. The survey data are being compiled and analyzed to provide the Council of Aviation Accreditation with recommendations. These ideas will assist in setting standards for aviation programs using distance education and distributive learning methods.

The primary goals of this comparative research focus first on discovering whether distance education and distributive learning are considered to be different from traditional classroom education. Through a comparison of the survey data to the literature review and content analysis, the research then focuses on determining distance education's strategic relevance to aviation education. To accomplish these goals, research is based on several assumptions and limitations. The widespread prevalence of distance education and its future role in all education (including aviation programs) are the accepted assumptions. The primary limitations to be considered are (a) that not all respondents will respond to the survey and (b) that not all respondents or other sources are interested in the study of distance education. Also, since the survey is unsupervised, interested respondents simply may fail to return the completed questionnaires.

To determine the material available on distance education, a content analysis examines available information. Telephone surveys, Web searches, and a literature review are performed to discover the current status of distance education and program accreditation. A wide range of professional career associations is contacted concerning the accreditation status of distance education programs. Also, the six regional accrediting bodies that make up the Commission of Secondary Schools are scrutinized to determine their status.

\section{Literature Review}

Extensive web searches gather newly published information regarding accreditation of distance education programs that are available on the World Wide Web. A literary review determines the status of distance education programs and analyzes other authors' opinions and findings regarding the accreditation of such programs. The 
authors review dissertations regarding distance education as well as articles published on the subject.

\section{Content Analysis}

To establish the most effective way for the aviation discipline to approach the subject of accreditation of distance education programs necessitates a review of how other disciplines are addressing the same issue. The content analysis assimilates information from Web searches and reviews conducted to determine updates in the various disciplines on the position of distance education. Prior research included randomly chosen interviews based upon interview availability. No additional interviews are currently needed. The findings reveal that, in general, most disciplines are either just beginning to approach the subject of distance education accreditation of programs or are not dealing with the issue at all.

Accreditation boards for various professions

The Accreditation Board for Engineering and Technology, Inc. (ABET) evaluates and accredits engineering, technology, and related programs. According to Ken Alston, Accreditation Analyst, ABET does not distinguish distance education components from traditional instructional methods of the past. Since the accreditation criteria require that accredited programs include laboratory experiences, programs delivered via distance education have difficulty fulfilling that requirement. Currently, many of ABET's accredited programs offer components of their programs via distance education means.

The American Assembly of Collegiate Schools of Business (AACSB)-now known as the International Association for Management Education (IAME)-formed a Distance Learning Task Force in 1997. By 1999 the task force had prepared a report, "Quality Issues in Distance Learning," that explored 17 recommendations on program features that require special attention when developing distance learning programs. The report highlights critical areas for both people developing distance learning programs as well as for peer reviewers. According to David Stephens, Utah State University business dean and task force chairperson, it is essential that the distance learning strategy be firmly based on the school's mission (AACSB, 1999). The task force findings are being used to modify accreditation standards for distance learning programs as well as to emphasize possible concerns specific to this mode of delivery. The AACSB's reach is felt around the world: it has integrated its program with accreditation institutions in Latin America, Europe and Asia. The IAME/AACSB Web site also has an e-business education section that addresses the demand for information and communication technologies in organizations.

The American Psychological Association (APA) provides no information regarding accreditation of distance education programs on its Web site. Its accreditation standards were established in 1996 and have not been modified. The Director of the Engineering Accreditation Commission (EAC) currently has a task force assessing the issue to decide if guidelines and standards are needed for engineering distance education courses. However, there are a few programs currently accredited with remote lab sites. The problem that the EAC faces is the feasibility of offering a degree program on a distance education basis when "hands-on" laboratory work is necessary. This is similar to ABET's problem. The EAC accreditation procedures (updated as of November 1,1999 ) do not include any reference to distance education.

The National Association of Schools of Public Affairs and Administration's (NASPAA) Web site provides extensive information regarding its position on distance education. A survey regarding the planning and implementation of distance education programs in this field was conducted in the spring of 1995, with 147 completion schools responding. A second survey was conducted by mail in September and October of 1996. 180 completed surveys were returned, a return rate of 52\% (NASPAA, 1998). The survey conducted in 1995 found that only 18 of the 147 responding schools had any Master of Public Administration (MPA) courses offered off-site through distance education means. Typically, these courses are either core or elective courses. Of the 18 , only three state that their distance education programs are a major part of their MPA program. Fifteen of the 18 schools offering courses via distance education consider support services and support staff as either critical or very important to the overall success of their distance learning programs.

In the phone survey conducted in 1996, the results revealed that there was an increase in distance education programs offered from the previous year. In $1995,20 \%$ of the respondents reported some level of distance education activity. By 1996 , however, the number increased to $38 \%$ of the schools reporting some distance education activity (Rahm \& Reed, 1998). The report concludes by stating that "...those reporting current or planned course or program delivery via distance learning technologies, the World Wide Web, or the Internet are more likely to say that these technologies will have overall good effects or overall very good effects on students, faculty, programs, and institutions" (p. 4).

\section{Regional accrediting bodies}

The views of distance education program accreditation held by the six regional accrediting bodies that make up the Commission of Secondary Schools (CSS) vary only in that one does not address the issue at all. CSS encompasses the Middle States Association of Schools and Colleges, the New England Association of Schools and Colleges, the 
North Central Association Commission of Schools, the Northwest Association of Schools and Colleges, the Southern Association of Colleges and Schools, and the Western Association of Schools and Colleges. This commission is responsible for ultimately accrediting college and university degree programs. Additionally, the Western Cooperative Education Telecommunications' (WCET) Principles of Good Practice for Electronically Offered Academic Degree and Certificate Programs establishes the core for the distance learning practices employed in varying fashion by the eight regional accrediting commissions (Eaton, 2000).

While the Middle States Association of Schools and Colleges offers no opinion on distance education, the New England Association of Schools and Colleges (NEAS\&C) is a recent convert to the accreditation of distance education programs. NEAS\&C has established a policy for the accreditation of academic degree and certificate programs offered through distance education; this policy is used in conjunction with standards for accreditation (NEAS\&C, 1998). NEAS\&C “...endeavors to enhance the quality of teaching. It encourages experimentation with methods to improve instruction" (Commission on Secondary Schools, 1998, p. 9).

The Northwest Association of Colleges and Schools (NASC) incorporates distance learning under the guise of continuing education and special learning activities. The Accreditation Handbook, developed in 1996 by the Commission of Colleges of the NASC, makes only simple provisions for the methods of distance education, regarding distance education as still only a minor entity with little bearing on the overall accreditation process.

The Southern Association of Colleges and Schools (SACS) creates a more detailed reference to distance education. In the Criteria for Accreditation, developed by the Commission on Colleges in 1998, several sections address the role of distance education.

The North Central Association has no specific statement regarding the status of accreditation of distance education programs. The general guidelines of the Criteria for Accreditation do not specifically mention or involve distance education, but “...their generality ensures that accreditation decisions focus on the particulars of each institution's own purposes, rather than on trying to make institutions fit into a pre-established mold" (North Central Association, 1998, p. 2). The organization reviews each program on an individual basis when evaluating accreditation for distance education program quality.

The Western Association of Schools and Colleges (WASC) is the first accrediting body of the six that specifically addresses the issue of distance education and accreditation of such programs. WASC continues to refine the process. In a Policy Statement on Distributive Learning and Technology-Mediated Instruction, the Association maintains that "WASC intends for its role in assuring institutional quality to be supportive of innovation and creativity. Distance education and technology-mediated instruction have already generated considerable creative approaches to teaching and learning" (Western Association, 1998, p. 1). In an attempt to assure the public of the standards of distance education programs, WASC asserts that "the accreditation process will continue to focus on the overall quality of an institution. Although there are many similar issues, distance education does raise quality issues that are distinctive from those relevant to on-campus programs" (p. 1).

\section{Higher education organizations}

The Council for Higher Education Accreditation (CHEA) commissioned the Institute for Higher Education Policy (IHEP) to research distance education versus traditional delivery. The group was tasked with determining themost significant difference between the two methods of delivery in the assessment method of students' work. In a traditional setting, faculty members review student work; but in distance education, program evaluation is conducted by administration with greater reliance upon outside consultants. "The quality assurance process therefore appears to be less process-driven, where there is a high value placed on consultation, consensus building and dialogue, and more orientated to 'bottom-line' or market-orientated results" (p. 1). Distance education produces new considerations in the accreditation process.

Current CHEA findings reveal that traditional accreditation measures may not be as suitable for determining the quality of distance learning. CHEA advocates the development of a competency-based review that concentrates on student outcomes (Eaton, 2001). Student outcomes refers to “... what students learn, what students achieve, and how they perform, whether full-time or part-time, degree-bound or engaged in ongoing education" (Eaton, 2001, p.1). While traditional core academic values continue as the basis of distance education, different measures prove more effective in determining quality learning.

CHEA (Eaton, 2001) offers several recommendations for the accreditation community to address, including (a) establishing a reliable and valid performance measurement for distance education, (b) requiring evidence of effective teaching methods, and (c) examining possible alternatives to the current traditional accreditation process.

The National Education Association (NEA), the nation's largest professional association of higher education faculty, also takes a proactive view of distance education accreditation. NEA, working with a leading on-line 
education company-Blackboard Inc, introduced a set of quality benchmarks for distance learning in higher education. The leaders of both organizations "...declared the 24 benchmarks essential to ensuring excellence in Internet-based learning" (NEA \& Blackboard, 2000). The interconnected benchmarks are divided into seven categories that include course development and structure as well as faculty support and evaluation/assessment. A complete listing and regular updates are posted on the IHEP website. The NEA continues to explore ways to ensure the quality of distance education.

\section{Federal government evaluation and programs}

According to the U.S. Department of Education's (U.S. $D E)$ accreditation guidelines, distance education is considered to be a method of delivery and not a separate program. Therefore, “....we will observe and evaluate, as part of our regular review of an agency for initial or continued recognition, the agency's compliance with the criteria for recognition, including the agency's compliance in accrediting distance education programs and institutions"(U.S. DE, 1999, p. 56614). There is no change in regulations for distance education and the scope of recognition.

Under Title IV of the Higher Education Amendment of 1998, two new programs were established that widen the range of students that can be enriched by distance education. First, the Distance Education Demonstration Program changes the parameters for distribution of financial aid and waives specific statutory and regulatory student aid requirements related to distance education (University of Continuing Education Association, 1999). Congress also appropriated $\$ 10$ million for the Learning Anytime Anywhere Partnership (LAAP). This program extends “... competitive grants to increase student access to high quality, technology-mediated learning opportunities that are not limited by the constraints of time and place" (Lekander, 1999, p. 1). The Fund for the Improvement of Post-secondary Education (FIPSE) administers the program. This investment in human resources and technology-mediated distance learning sets a national precedent and an opportunity for lifelong learning.

While many factors germane to distance education (such as quality of delivery and student learning) are difficult to define and to measure, the accrediting institutions agree that precepts must be established that address both traditional and distance education. Evaluations should involve course delivery, course content, the number of degree programs available to be completed via distance education, and the methods of distance education used. Attention to these factors will help to determine future evaluation guidelines and ultimately reflect the accreditation of entirely distance education programs.

\section{Benchmark}

\section{METHOD}

The purpose of this research endeavor is to benchmark and evaluate the accreditation status of aviation distance education programs in the United States. In order to conduct a content analysis of all information currently available on distance education accreditation, phone interviews, web searches, and literary reviews were performed.

\section{Content Analysis}

Information was gathered and analyzed by multiple means, including content analysis. Content analysis is defined as ". . . any technique for making inferences by systematically and objectively identifying specified characteristics of messages." (Frankfort-Nachmias \& Nachmias, 1996, p. 324). Borg defines content analysis as "... .a research technique for the objective, systematic, and quantitative description of the manifest content of communication" $(1963$, p. 256). The purpose of content analysis is to (a) compare communication, (b) determine content versus objective, and (c) find any trends in communication content (Bowen, 1998). This method was chosen because ". . utilization of this tool directs the researcher to apply consistent criteria in literature analysis to look objectively at the research question, regardless of effect on the stated hypothesis" (p. 1). By using content analysis, information is gathered ". . . which allows the researcher to address study questions or a stated hypothesis" (p. 1).

\section{Literary Review}

Extensive web searches gathered any newly published information regarding accreditation of distance education programs that are listed on the World Wide Web. A literary review determined the status of distance education programs and analyzed other authors' opinions and findings regarding the accreditation of such programs. Dissertations regarding distance education as well as articles published on the subject were reviewed. This process is discussed in detail in the Introduction section of this paper.

\section{Participants}

The first element of this research study was to develop an accurate database of aviation education programs in the United States. For the original white paper, the participants of this study initially consisted of intentionally-selected discipline members of the Association of Specialized and Professional Accreditors (ASPA) as well as members of the six regional accrediting bodies of the Commission of Secondary Schools (Middle States, New England, North Central, Northwest, Southern, and Western) and various aviation experts involved in the 
issue of aviation distance education program accreditation.

For the second round of study, educational institutions listed in the Collegiate Aviation Guide: Reference Guide of Collegiate Aviation Programs (a publication of the University Aviation Association) were asked to participate in the survey (see Appendix 1). Each institution in this directory of colleges and universities offers courses and/or majors in aviation. Additionally, members of the University Aviation Association were included in the survey. The entire population totals 214 members.

\section{Survey}

The Distance Education Aviation Program Survey is a structured questionnaire composed of questions that require individual responses. According to How to Conduct Self-Administered and Mail Surveys (Bourque \& Fielder, 1995, p.7), "... the motivation to seek information must be high ... it is imperative that the questionnaire be completely self-sufficient, or to be able to "stand alone." Furthermore, "One indication of motivation is that a group decides it needs to find out something about itself . . . Another indicator of motivation is the amount of loyalty that individuals have to the group being studied" (p. 25). It is the intent of the researchers to obtain a high response rate, thus obtaining a greater perception of all outcomes and opinions.

One disadvantage of this unsupervised survey is the fact that there is no direct information concerning answerability of questions. Therefore, each question must be clear. Additionally, contact information for the survey conductor must be clearly stated on the questionnaire.

The written survey (see Appendix 1), Distance Education Aviation Program Survey, was drafted by the authors. The survey was designed quantitatively and qualitatively to examine the state of distance education aviation programs. Contained within the survey were four pages of required response data. Page one consisted of seven Likert-scale questions to be answered by the entire survey population. Therefore, industry members of CAA and UAA, although not directly associated with an aviation education program, still had the opportunity to comment on the importance of distance education initiatives from their unique perspectives. Part II of the survey was to be completed by those members of the survey population who currently serve students via distance education programs. Open- and closed-ended questions were included within the survey to allow a mix of qualitative and quantitative information to be gathered.

The Distance Education Aviation Program Survey was prefaced with a letter to each member of the survey population (see timeline, Table 1, below). The letter provided both rationale and background for the survey; it also appealed for thoughtful responses. Respondents were asked to reserve between 10 and 20 minutes to complete the survey. While the initial mail survey was conducted in March of 2000, a follow-up survey was mailed in June of 2000 to those educators who had not returned the survey (according to the information provided by data coding).

\section{Table 1}

\begin{tabular}{ll}
\hline \multicolumn{2}{l}{ Distance Education Survey Timeline } \\
\hline \\
March 7, 2000 & Initial survey request sent \\
March 26, 2000 & Initial survey response deadline \\
June 6, 2000 & Follow-up survey sent \\
June 28, 2000 & Follow-up response deadline
\end{tabular}

\section{Reliability}

Reliability is based on the probability a specific research tool will generate the same response if repeated (Babbie, 1999). Based on guidelines for developing survey instruments, the reliability of the data should be fairly high.
All subjects were presented with a standardized questionnaire and instructions. The questions were carefully worded based on the findings and recommendations of the pretest. This careful construction significantly reduces the individual subject's unreliability 
(Babbie, 1999). The survey responses may be considered to be approximate indicators of the participants' viewpoints as related to distance learning overall and within the context of their respective institutions.

\section{Validation}

In an effort to eliminate abstruseness and error from the survey, a pretest was conducted. According to Bourque and Fielder (1995, p.89), "The results [of pretests] should be carefully evaluated and used in making changes to the questionnaire and the study design." Therefore, a focus group and peer analysis analyzed the quality and content of the draft survey methodology that would be used in the near future to ascertain the status of accreditation of distance education programs.

To establish the most effective way for the aviation discipline to approach the subject of accreditation of distance education programs, a review of how other disciplines are addressing the same issue is necessary. Web searches and review were conducted to determine any updates in the various disciplines on the position of distance education. The earlier interviews were chosen randomly and based upon availability to be interviewed. No additional interviews were employed for the revised white paper. It was generally found that most disciplines have either just begun to approach the subject of distance education accreditation of programs or have not explored the issue at all.

\section{RESULTS}

The preliminary survey data were coded for analysis. Out of the survey population of 214 selected for the survey, 97 usable surveys were returned. Three additional people responded saying the survey did not apply to them at all and one survey was returned by the post office. That makes a response rate of $47 \%$ and a usable survey response rate of $45 \%$. The entire survey population answers Part I of the survey. Part II of the survey applies only to individuals affiliated with a distance education aviation program. While $100 \%$ responded to Part I as planned, 39\% responded to Part II. Over one-third of the respondents are currently involved with a distance education aviation program. Many more respondents are with schools that have distance education programs but that are not yet available for the aviation courses.

Part I covers distance education initiatives based on a Likert scale (see Appendix A for survey). According to $90 \%$ of the respondents, their university is interested in distance education, with $67 \%$ agreeing that distance education is becoming a critical issue in aviation education and $77 \%$ planning to pursue the issue now or in the near future. Ten percent of respondents have no plan to pursue distance education. $95 \%$ of respondents agree that CAA should monitor other accrediting bodies' responses to the demand of distance education, and $84 \%$ think CAA should consider the development of academic standards for distance education programs. While $82 \%$ agree that regional accrediting bodies should meet regularly to discuss issues of quality in distance education programs, $15 \%$ remain neutral on the issue. Several respondents wrote in comments expressing a desire for more thorough and specific questions.

The findings of Part II provide a greater variance of answers reflective of the differences between newly implemented distance education programs and those that have been established for some time. For the respondents answering this section, $53 \%$ offer one to ten distance education courses in each academic year, while $18 \%$ offer over 50 courses. Out of all these programs, $50 \%$ of respondents' programs offer only undergraduate level courses, $8 \%$ offer only graduate level courses, and $37 \%$ provide courses at both levels. $5 \%$ did not respond. On-line communication is the predominant method of course delivery, with $39 \%$ selecting that option; this figure couples with the $32 \%$ of respondents who use the Internet. Videotapes continue to be significant in the on-line area, with $11 \%$ indicating this as the predominant method. There is some ambiguity in this area due to the wording of the questionnaire. The authors view on-line communication as e-mail, but it was not defined in the survey as such. Fourteen percent consider other methods more predominant, including such methods as interactive television. Survey questions encompassing educational services provided to students, as well as the manner in which student work is submitted and evaluated, are covered in Table 2. 


\section{Table 2}

\section{Measures Used to Determine Student Outcomes}

\begin{tabular}{lcc}
\hline Measure & Raw & Apply \\
\hline Course completion statistics & 25 & $66 \%$ \\
Employment/placement & 9 & $24 \%$ \\
Student evaluations & 21 & $55 \%$ \\
Professional organization recognition & 5 & $13 \%$ \\
Employer evaluations & 7 & $18 \%$ \\
Passage of licensing/certificate exam & 16 & $42 \%$ \\
Other & 1 & $3 \%$ \\
\hline
\end{tabular}

Note. Respondents were encouraged to check all responses that applied to their program.

Numerous questions also allow for write-in information in the "other" category. Some of the questions contribute a range of answers. In terms of educational services provided to students, some on-line programs include extensive library facilities, testing center use, site staffing, message boards, and a hotline number. To help motivate students, some programs offer field trips, team projects, and caucus opportunity. E-mail messages are used to motivate students in $81 \%$ of the programs, followed by $46 \%$ who use phone calls. Chat rooms provide encouragement at $35 \%$ of the institutions, with $14 \%$ sending individualized letters to students. In the area of testing, several schools make use of onsite faculty and staff to proctor or monitor tests as well as to provide student assistance. Faculty members complete the overwhelming majority of the evaluation of student work. Only a few programs also include administrators in the process. For one program, the employer is part of the evaluation completion. Measures used to determine student outcomes are the focus of Table 3. 
Table 3

Methods Used to Communicate between Students and Faculty

\begin{tabular}{|c|c|c|c|c|}
\hline \multirow[b]{2}{*}{ Method } & \multicolumn{2}{|c|}{ Services $^{\mathbf{a}}$} & \multicolumn{2}{|c|}{ Work $^{\mathrm{b}}$} \\
\hline & Raw & Apply & Raw & Apply \\
\hline Fax exams & 13 & 34 & 13 & 34 \\
\hline Toll-free numbers ${ }^{c}$ & 19 & 50 & -- & - \\
\hline E-mail & 33 & 87 & 25 & 66 \\
\hline Other & 8 & 21 & 20 & 53 \\
\hline
\end{tabular}

Note. Respondents were encouraged to check all responses that applied to their program.

Educational services provided to students

${ }^{b}$ Methods used for students to submit work and its evaluation

"Toll-free numbers" does not apply to the evaluation of student work. No data were collected in this area.

Regarding accreditation of the respondents' affiliated institution, $89 \%$ are nationally accredited, while $8 \%$ are not and have no accreditation pending. An additional $3 \%$ did not respond. The NCAA is the accrediting body for $26 \%$ of universities, and SACS accredits $13 \%$ of the institutions. Of the distance education programs, a total of $45 \%$ are accredited, with $5 \%$ through NCAA and $5 \%$ through FAA. Three percent of the programs have accreditation pending, while another $37 \%$ are not accredited.

The final question of the survey is open-ended and asks respondents what steps should be taken to establish standards for aviation distance education course offerings. Those who responded to Part II were asked to provide recommendations for this section. Of the $42 \%$ who answered this section, many stated that it is too soon to tell what steps need to be taken. Three respondents stated that existing standards should be followed. Additional work with accrediting groups is highly encouraged, as is promoting testing and authentication standards and enhancing the necessary technical standards for the students and the faculty. Many requested more direct study that would compare distance education needs to those of traditional classrooms. The responsibility of offering guidelines to emerging programs is reported as a primary need for this type of research.

\section{CONCLUSION}

The findings of the content analysis correlate with the survey results. Both the accrediting bodies and the aviation programs are at the same level of development regarding distance education programs. While many schools and bodies have fully embraced distance education for some time, the majority is gradually easing its way into the process. However, a few holdouts remain. Determining the actual differences and similarities between distance education and traditional course delivery will enable focus to be centered on the significant areas to maximize learning and reduce inefficiency relative to distance teaching methods.

While many factors relative to distance education are difficult to determine and just as difficult to measure, it is agreed that standards must be set regarding accreditation of such programs. Suggestions regarding these standards may include (a) course delivery, (b) course content, (c) the amount of a degree program available to be completed via distance education, (d) the manner and criteria for which 
work is assessed and authenticated, and (e) the method or combination of methods for distance education used. These standards will help establish guidelines for distance education programs and ultimately control their accreditation. Establishing standards now will provide a guide for emerging programs. Distance education is becoming an increasingly significant issue in aviation education, as its role is expanding in education as a whole.

PROPOSAL FOR FURTHER RESEARCH

The authors recommend that further research be conducted to draw direct comparison between traditional classroom delivery and distance education situations. The applicability to aviation education should be focused on as the evaluation of learning is explored among aviation schools. While a final report has been written that draws upon these preliminary findings, data will continue to be gathered from the survey. This information will then be used to provide periodic reports to the CAA Board of Directors to incorporate/examine such items as types of distance education programs, accreditation status of these programs, and outcomes of such teaching.

Brent Bowen is the University of Nebraska Foundation Distinguished Professor in Aviation. He serves as director for the Aviation Institute and as Director of Aviation and Transportation Policy and Research at the University of Nebraska at Omaha. Additionally, Dr. Bowen is the program director and principal investigator for the National Aeronautics and Space Administration funded by the Nebraska Space Grant Consortium and NASA EPSCoR program. He is an airline transport-rated pilot and an aviation safety counselor for the Federal Aviation Administration.

Nanette Scarpellini is a graduate research assistant in the NASA Space Grant College and Fellowship program for the University of Nebraska at Omaha Aviation Institute and the assistant editor for the Journal of Air Transportation World Wide. She is pursuing a Master of Public Administration degree with an Aviation Administration concentration. Ms. Scarpellini holds a Bachelor's degree in Journalism and Psychology with an Advertising concentration from the Ohio State University and a Certificate of Organizational Development and Training from New York University.

Mary Fink is the Coordinator of Research and Special Programs for the Aviation Institute. She holds a Bachelor's degree in Aviation Administration from the University of Nebraska at Omaha and is currently pursuing a Master of Public Administration degree, Aviation Concentration, at the UNOmaha. Ms. Fink instructs Special Topics in General Aviation for the Aviation Institute. She recently completed a term serving on the University of Nebraska at Omaha Graduate Council, Committee on Policy and Planning. 


\section{REFERENCES}

Ad hoc Committee for Distance Education. (1998). A report to the Council on Aviation Accreditation Board of Directors. [On-line]. Available: http://cid.unomaha.edu/ unoai/caa/de21398.html

American Assembly of Collegiate Schools of Business. (1999). AACSB Home page. [On-line].

Available:http:///www.aacsb.edu

Babbie, E. (1999). The basics of social research. Belmont, CA: Wadsworth Publishing Company.

Borg, W. (1963). Educational research: An introduction. New York: David McKay Co., Inc.

Bourque, L. \& Fielder, B. (1995). How to conduct self-administered and mail surveys. Thousand Oaks, CA; SAGE.

Bowen, B. (1998). Content Analysis. [On-line]. Available: http://cid.unomaha.edu/ unoai/avn8120/tools/definitions/contentanalysis.html

Commission on Secondary Schools: Middle States Association of Colleges and Schools. (1998). What is accreditation. [On-line]. Available: http:www.css-msa.org/accredit.html

Council for Higher Education Accreditation. (1998). CHEA Home page. [On-line]. Available:

http://www.chea.org/

Distance Education Training Council. (1997). DETC accreditation overview. Washington, DC: Authors.

Distance Education Training Council. (1998). 1998 Distance education survey: A report on course structure and educational services in distance education and training council member institutions. Washington, DC: Authors.

Eaton, J.S. (2000). "FOCUS: assuring quality in distance learning." Council for Higher Education Accreditation reprinted from The Presidency Fall 2000: American Council on Education.

Eaton, J.S. (2001). "The competency standards project: Another approach to accreditation review." Council for Higher Education Accreditation Website. Online. Available: http://www.chea.org/Commentary/core-values.cfm

Frankfort-Nachmias, C. \& Nachmias, D. (1996). Research methods in the social sciences ( $5^{\text {th }}$ ed.). New York: St. Martin's Press.

Lekander, B. (1999). Learning anytime anywhere partnerships (LAAP). [On-line]. Available:

National Association of Schools of Public Affairs and Administration. (1998). NASPAA distance learning survey. [Online]. Available: http://cid.unomaha.edu/ wwwpa/nasdist.html

National Center for Education Statistics (1999). Statistical analysis report December 1999: Distance education at postsecondary education institutions: 1997-1998. [On-line]. Available: http:nces.ed.gov/pubsearchinfo.asp?pibid=200013.

NEA and Blackboard Inc. study finds 24 measures of quality in internet-based distance learning. (2000, March 21). Institute for Higher Education Policy. [On-line]. Available: http://www.ihep.com

New England Association of Schools and Colleges. (1998). Commission on independent schools: Standards for accreditation. [On-line]. Available:http://neasc.org/cis/cisstand.html

North Central Association of Schools and Institutions. (1998). An overview of accreditation: The criteria for accreditation. [On-line]. Available: http://www.ncacihe.org/overview/ovcriteria.cfm

Rahm, D. \& Reed, B. (1998). The use of distance learning technologies, the World Wide Web, and the internet for course delivery in programs of public affairs and administration. [On-line]. Available: http://cid.unomaha.edu/ wwwpa/nasdir.html

University of Continuing Education Association. (1999). Regulatory fact sheet: Promoting high-quality distance education: Distance education demonstration programs and learning anytime anywhere partnerships. [On-line]. Available: http://www.nucea.edu/DELAPP.htm

U.S. Department of Education. (1999). Higher Education Act of 1999, Fed. Reg. 64, 602.3, 20 U.S.C. 10996. [On-line]. Available: http:www.access.gpo.gov/nara/index.html

Western Association of Schools. (1998). Policy statement on distributive learning and technology-mediated instruction. [On-line]. Available: http://www.wascweb.org/senior/GUIDE/POLICY/HTM 


\begin{abstract}
AUTHOR NOTE
The authors of this paper are: Brent Bowen, University of Nebraska at Omaha Aviation Institute; Nanette Scarpellini, University of Nebraska at Omaha Aviation Institute; and Mary Fink, University of Nebraska at Omaha Aviation Institute; Aimee Freeman, University of Nebraska at Omaha Aviation Institute (now at Elliott Aviation, Omaha, Nebraska).

The authors wish to extend their thanks for input and guidance regarding this study to the Council on Aviation Accreditation and the Ad Hoc Committee for Distance Education. Additional thanks go to Jason Kurz and Tracey Cullan for their aid in data input analysis and to Bill Metz, Amy Tegeder, and Jocelyn Wachal who reviewed this final document.

Correspondence concerning this study on aviation accreditation of distance learning programs may be addressed to Nanette Scarpellini and Mary Fink; University of Nebraska at Omaha Aviation Institute; 6001 Dodge Street; Allwine Hall 422; Omaha, Nebraska 68182-0508. Electronic mail may be sent via the Internet to Nanette Scarpellini [nscarpel@unomaha.edu] or Mary Fink [mschaffa@unomaha.edu].
\end{abstract}


Journal of Aviation/Aerospace Education \& Research, Vol. 11, No. 1 [2001], Art. 2

, 